\title{
An Edition of Unpublished Greek Ostracon from Cairo Museum
}

This paper includes the edition of an unpublished Greek ostracon of the Roman period; this ostracon is from Elephantine. It is belonging to Cairo Museum, and registered under the special number 18955 .

This ostracon has a light brown color. It consists of eight incomplete lines. Its actual dimensions are $6 \mathrm{~cm} . \times 5.6 \mathrm{~cm}$. This ostracon is broken on both left and right hand sides, so it has no margins from these two sides. There is a very narrow margin at the top, but at the bottom, it has a margin of $1.5 \mathrm{~cm}$.

This text is a receipt for a tax that paid in a rate of $20 \mathrm{dr} .2 \mathrm{ob}$. in the fifth year of the Roman Emperor Antoninus (142 AD.) as appears on lines 5, 6. Also, on the eighth line appears the month and the just day on which the tax collected (Paoni 12) $=(6$ June $)$.

First and second lines show the collectors of the tax who are lessees of the sacred gate of Syene. In the meanwhile, the third and fourth lines show the name of the taxpayer.

The verso is blank.

\section{Recto:}

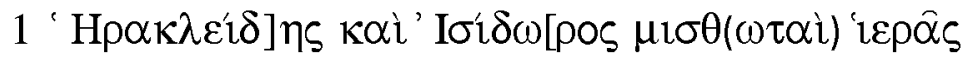

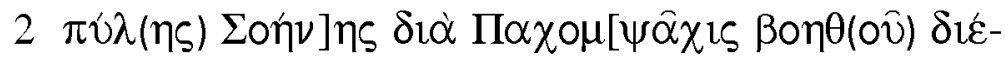

$3 \gamma p \alpha \psi(\varepsilon \nu)]$ T $\alpha \chi v o v \beta i \varsigma \Delta[$ the rest of the

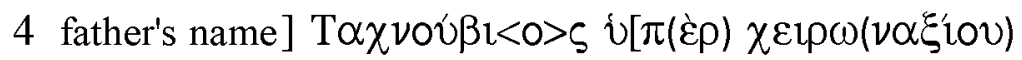

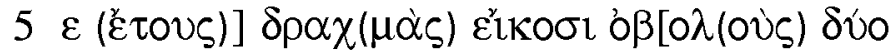

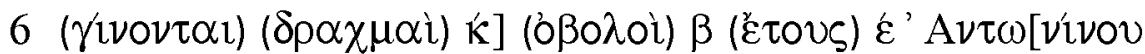

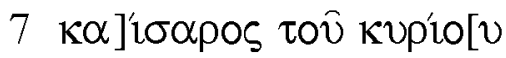

8 vac. $\Pi \alpha \tilde{v} \nu$ i $1 \beta$

\section{Translation:}

"[Heraclid]es and Isidoros, [Lessees of the sacred gate of Syene], through Pachompsachis the assistant. Tachnoubis, son of D[.....], grandson of Tachnoubis, has paid for the [trade tax], for the $5^{\text {th }}$ year twenty drachmas [two] obols, [the total $20 \mathrm{dr}$.] $2 \mathrm{ob}$. The $5^{\text {th }}$ year of Antoninus Caesar our Lord, Paoni 12"

\section{Commentary:}

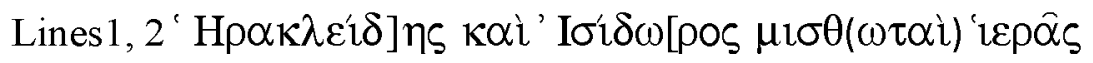

$\pi \hat{v} \lambda(\eta \varsigma) \Sigma o \eta \nu] \eta \varsigma$ for these two collectors see W.O. 181-184. They are known from a large number of ostraca as lessees of the sacred gate of Syene, they were official collectors and appeared first time in the reign of the Roman emperor Trajan.11

Line $2 \Pi \alpha \chi \circ \mu[\psi \hat{\alpha} \chi 1 \varsigma \beta \circ \eta \theta(\circ \hat{v})$ the receipts issued by Heraclides and Isodoros shows that their assistant was sometimes Pachompsachis (as in this receipt), Patachimis, or 


\section{An Edition of Unpublished Greek Ostracon from Cairo Museum}

Sarapion. Cf. O.Wilck.II, nos. 181-184, 188-193, O.Tait. II, nos. 966, 967, 1066, O.Leid. no. 182, O.Eleph.Daik. no. 30.

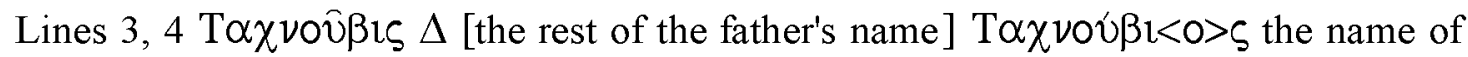
the taxpayer Tachnoubis appears completely on line 3 . Only the first letter of the taxpayer's father's name appears at the end of line 3 and it may be finished on the beginning of line 4 . Then the name of the grand father appears on line 4 as T $\alpha \chi v 0 \hat{v} \beta i \varsigma$ but it must be in

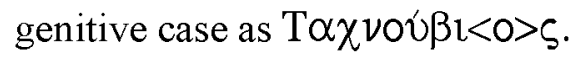

Line $4 \hat{v}[\pi(\dot{\varepsilon} \rho) \chi \varepsilon 1 \rho \omega(\nu \alpha \xi i o v)$ the tax collected in this receipt may be the trade tax $\chi \varepsilon 1 p \omega \nu \alpha \xi 10 \nu$. This suggestion depends on the rate which appears on lines 5, 6 .

In general $\chi \varepsilon 1 p \omega \nu \alpha \xi \xi 10 \nu$, was a tax on handicraftsmen. $\chi \varepsilon 1 p \omega \nu \alpha \dot{\alpha} 10 \nu$ was assessed on every person, male and female, engaged in any occupation or profit, including apprentices aged fourteen and over. The father whose minor son was apprenticed in trade, had to pay the $\chi \varepsilon \omega \omega \nu \alpha \xi 1 \alpha \tau \eta \bar{\zeta} \tau \dot{\varepsilon} \chi \nu \eta \zeta$, and a female weaver paid the $\chi \varepsilon 1 p \omega \nu \alpha \xi 1 \alpha$ to the nomarch's account. In addition, the soldier who purchased a loom for 13000 drachmae certainly exploited it and, consequently, was liable to the taxes due on the trade. 1

The $\chi \varepsilon 1 p \omega \nu \alpha \xi_{10 \nu}$ was a state tax on the trades. Craftsmen and merchants paid individually a special tax for the right to practice their trade, so the $\chi \varepsilon\llcorner\omega \omega \nu \alpha \xi$ iov was a tax that had to be paid for the license to exercise that trade. All artisans were liable to this tax. Even the humblest trades did not escape as "baggage porters, donkey men, masons". For each trade there was a special rate. The tax was quite independent of the earnings, custom and scale of business of the particular merchant or craftsman. In each class, and there must have been as many classes as trades, everybody paid the same amount. 3

In the prehistory of most cultures, potters and basket makers were generally the first specialized workers in their appearance. Thereafter the weaving of basketry was relatively developed to the weaving of textiles for clothing and other kinds of covers. Egypt was famous for two of its manufacturers, linen and papyrus. In the third century, Egypt expanded its production of glass and became, with Syria, a major exporter of that commodity. 4

The weavers of the much prized linens were the aristocrats of the craft, and they were often co-operating to train children, both boys and girls and both free and slave. Those children, who were taken on as apprentices, were starting between ten and thirteen years old. The apprenticeship was expanded from one to three years and sometimes increases for another year or two. 4

Artisans who appeared in the Roman period were builders, carpenters, butchers, stonecutters, bakers, potters, bricklayers, brick makers, barbers, shoemakers, dyers, fullers, embroiderers who enhanced the weavers' products, also there were the undertakers, the embalmers, and the grave diggers. 4 


\section{An Edition of Unpublished Greek Ostracon from Cairo Museum}

In a very rich Roman family, there were six slaves trained as stenographers, two copyists, a scribe, a barber, a cook, and a repairman. 4

As such as we encounter the merchants and the storekeepers who dealt in single product, we encounter also the "everything emporium". In many trades the workers were organized in a guild. Guilds of bread makers, oil merchants, bronze welders, beer merchants are existed in the fourth century and later, while guilds of donkey drivers, weavers, potters, glassmakers, fullers and dyers, river pilots, skippers, hieroglyph carvers, salt merchants, and shoemakers are likely in existence earlier. 4

Under Augustus, various trades were organized into guilds which the government then used to facilitate the collection of the capitation taxes and requisitions placed on its members. As the guild was liable for the trade taxes of its members, if one member could not pay or had turned to flight, the remaining members bore the cost themselves. 10

Merchants and craftsmen paid taxes on most of the things they traded in, such as oil, bronze and bricks and on licenses, such as the privilege to sell linen. Brewers were taxed on the beer they sold. Fishermen had to pay for the right to catch fish in the Fayum canal.

http://www.reshafim.org.il/ad/egypt/economy/taxation.htm

The artisan-tax was levied not on the artisan qua craftsman but only on the actual exercise of his skill. If he does not practice his craft, no action will lie against him for nonpayment of the tax. 5

The aristocracy of the craftsmen was formed by the goldsmiths, silversmiths, and jewelers, who from the nature of their trade had to carry some stock of expensive goods. 2 


\section{Bibliography.}

1 - Adam Bulow-Jacobsen, Proceedings of the $20^{\text {th }}$ International Congress of Papyrologists, Copenhagen, Published by Museum Tusculanum Press, 1994.

2- A.H.M. Jones, The Later Roman Empire 284-602, Published by JHU Press, 1986.

3- Jules Toutian, The Economic Life of The Ancient World, 1979.

4- Naphtali Lewis, Life in Egypt under Roman Rule, 1985.

5- Naphtali Lewis, On Government and Law in Roman Egypt, 1995.

6- O.Bodl. Greek Ostraca in the Bodleian Library at Oxford and Various Other Collections, I, ed. J.G. Tait. London 1930. II, Ostraca of the Roman and Byzantine Periods, ed. J.G. Tait and C. Préaux. London 1955. III, Indexes, compiled by J. Bingen and M. Wittek. London 1964.

7- O.Eleph.Daik. Wagner, Guy, Elephantine XIII: Les papyrus et les ostraca grecs d'Elephantine, Mainz 1998.

8- O.Leid. Greek Ostraka: a Catalogue of the Greek Ostraka in the National Museum of Antiquities at Leiden, with a Chapter on the Greek Ostraka in the Papyrological Institute of the University of Leiden, ed. R.S. Bagnall, P.J. Sijpesteijn and K.A. Worp. Zutphen 1980.

9- O.Wilck.II, Griechische Ostraka aus Aegypten und Nubien, ed. U. Wilcken. LeipzigBerlin 1899.

10- S.R. Liewelyn, R.A. Kearsley, New Documents Illustrating Early Christianity, Published by Wm. B. Eerdmans Publishing, 1997.

11- Wallace, S. L., Taxation in Egypt from Augustus to Diocletian, Princeton, 1938.

- Duke Data Bank of Documentary Papyri, CD.Rom, Published by Packard Humanities Institute. On line version at,

http://www.perseus.tufts.edu/Texts/papyri.html.

- http://www.reshafim.org.il/ad/egypt/economy/taxation.htm 
An Edition of Unpublished Greek Ostracon from Cairo Museum

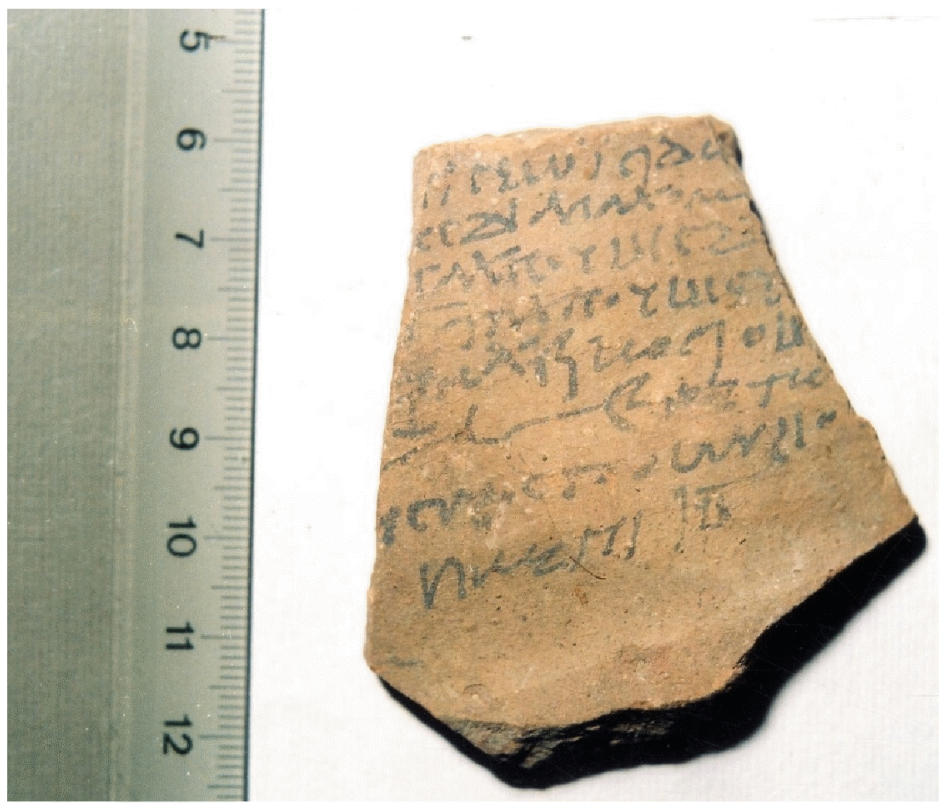




\title{
Receipt for the tax for the expense of recruit, provisions, and other expenses
}

\author{
O.Cairo Mus. Sr. 18955 \\ $4.1 \times 9.4 \mathrm{~cm}$. \\ Prov. Elephantine
}

This ostracon has a reddish brown color of pottery. There is a small break on the left hand side cause the disappearance of some letters on that side. This ostracon consists of six incomplete lines about a tax for the expense of recruit and provisions and other expenses. The receipt was written on the recto, the verso is blank.

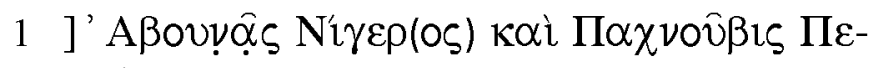
$\tau о \rho \zeta(\mu \eta \dot{\eta} \theta 0 v)$

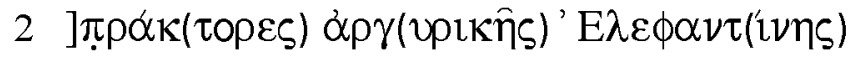

$\delta 1 \dot{\alpha}^{\prime} \mathrm{A} \nu \tau \omega v^{\prime} \mathrm{ov}$

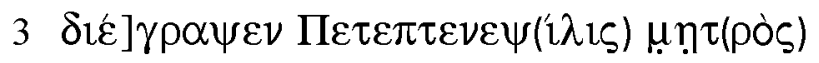

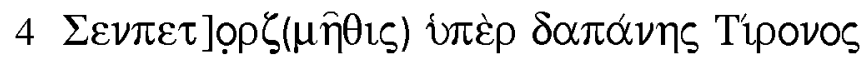

$$
\kappa] \alpha i ̀
$$

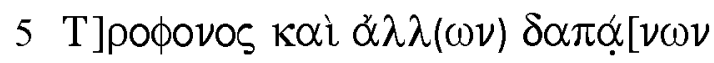

6 ] // $\prod \alpha \hat{v} \underline{y}[\mathrm{l}$

"Abounas son of Niger and Pachnoubis son of Petorzmithes, collectors of taxes in money of Elephantine, through Antonius. Peteptenpsilis, his mother Senpetorzmithis, has paid for the expense of the recruit and provisions and other expenses. (Marcus and Verus, Caesars our lords) Paoni"

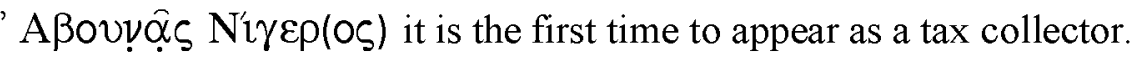

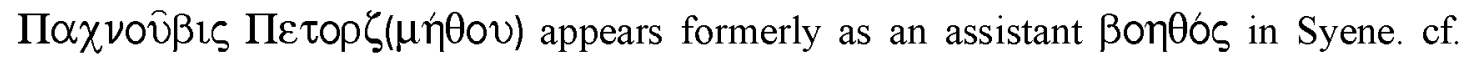
O.Wilck.II, no. 250 (AD. 163).

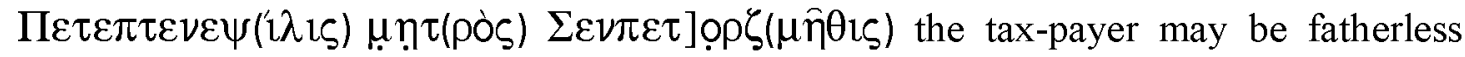
$\dot{\alpha} \pi \alpha \tau \omega \rho$, It is also possible to have a legitimate father, but not intended to recognize the father because of social differences or the like.

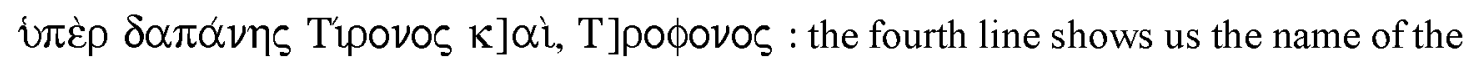
first tax "the expenses recruitment" $\delta \alpha \pi \alpha \nu \eta \varsigma$ tipovos. We find that the word tiro, tironis is a word of Latin origin means recruiting and often found in the case of genitive plural, but perhaps the writer mixed between the Latin word form by letter "o" and the Greek letter " $\omega$ " and that at the root of the word, but there is no doubt that he made a mistake at the end of the genitive singular that he wrote tipovov instead of tipwvos. If we try to follow the imperial Roman soldier from his enlistment onward, we find that he passes two stages: an examination (probatio) of eligibility and fitness to serve, performed by the governor's staff, and enrollment in an actual military unit. In probatio, prospective recruits seem to have had to prove their legal status (free birth and free status were required; Roman citizenship was required in the praetorians and legions). 6

The second stage: sacramentum recruiter performs an oath of allegiance. 


\section{An Edition of Unpublished Greek Ostracon from Cairo Museum}

The new recruits do not practice their military, despite their oath and travel to their unit until their names were inserted in the lists of the military. In normal cases the government authorities were sending a letter to the military unit to record new recruits and they register and include their names and ages, as well as some special grades or physical strength and the like. Their recruitment date and register was part of their identity.

The branches of military service in the Roman era was as follows:

1 - praetorians, belonging to the Imperial Guard.

2- legions, (main unit in the Roman army).

3- alae, army wing or left or right fleet.

4- cohorts, battalions (tenth part of the legion).

5- fleets. 5

The fifth line shows the second tax Tpoфovos, which means the army supplies (military supplies that help to survive). The Eastern Desert in which the Roman soldiers presented from the Red Sea to the borders of the Nile Valley in order to protect convoys traveling through these roads as well as workers in the quarries and mines, as it was for these soldiers an important role in the construction, maintenance and preserve the desert roads, this requires spending a long time in the desert away from the Nile Valley, which makes the provision of supplies is very important to meet the needs of these soldiers. 2

Supplying the army with food and grain, weapons and clothing is a key part of direct tax imposed on the residents of the countries. However there does not seem to be a significant increase in the tax burden as a direct result of the demands of the military. 4

Some provinces and cities coined particular coin to pay for the soldiers who walk through their territory, to get the right to claim to provide places to live and rest while performing their official duties. But unfortunately, some of the soldiers were using violence, oppression and greed towards the local population. The presence of additional forces in any area means providing additional supplies. 8

As Egypt was one of the rich regions it was providing supplies and animals for important military campaigns to other provinces, so we find that it was being confiscated animals for long-term periods. The state also imposed on residents sell their animals at specific prices less than their real value. Therefore, we find that some animals, such as mules were bred specifically for this purpose. 1

The presence of the army in different provinces, and perhaps in the different places in the same province means that there is a comprehensive and unified system to supply the army. The market has been active due to the needs of the soldiers of grain and foodstuffs, meat and alcohol, iron, wood and building materials, also the replacement of draft animals and horses, leather and clothing.

The army has not been self-sufficient; although the soldiers were producing some of the products widely as they were planting grain in certain limited areas as well as the cultivation of herbs for animals. Most of the supplies reached the camps of soldiers either from the same region in which they reside or regions of the relatively short distances. The state encourages the production of more crops due to the increased consumption of wheat 


\title{
An Edition of Unpublished Greek Ostracon from Cairo Museum
}

and grain, and this has led to a large proportion of the profit because the use of the army of the grain used to be anyway in the form of taxes or rents in kind. 3

The royal treasury paid out significant amounts to ensure the provision of foodstuffs (trophe) for salaried soldiers $\mu l \sigma \theta 0 \phi$ ópol (mercenaries) such as the garrisons of Syene/Elephantine who drew rations in kind, and pay in cash from the royal treasury, even the trophe for the troops was levied via assessments in kind.7

\author{
Shereen Abd Elgany Aly
}

\section{Bibliography:}

1- Colin E.P.Adams, Land Transport in Roman Egypt, A Study of Economics and Administration, 2007.

2- Colin E.P.Adams, Supplying the Roman Army, ZPE. 109, Germany, 1955.

3- J.B. Campbell, The Roman Army, 31 BC-AD. 337.

4- J.B. Campbell, War and Society in Imperial Rome,31 BC-AD 284, Published by Routledge, 2002.

5- M.P.Speidel and R.Seider, A Latin Papyrus with a Recruit's Request for Service in the Auxiliary Cohorts, the Journal of Egyptian Archaeology, vol.74, 1988.

6- Paul ErdKamp, A Companion to the Roman Army, 2007.

7- Pierre Briant, From Cyrus to Alexander

8- Richard Alston, Soldier and Society in Roman Egypt. Published by Routledge, 1998.

9- U.Wilcken. Griechische Ostraka aus Aegypten und Nubien, Leipzig-Berlin 1899. 
An Edition of Unpublished Greek Ostracon from Cairo Museum

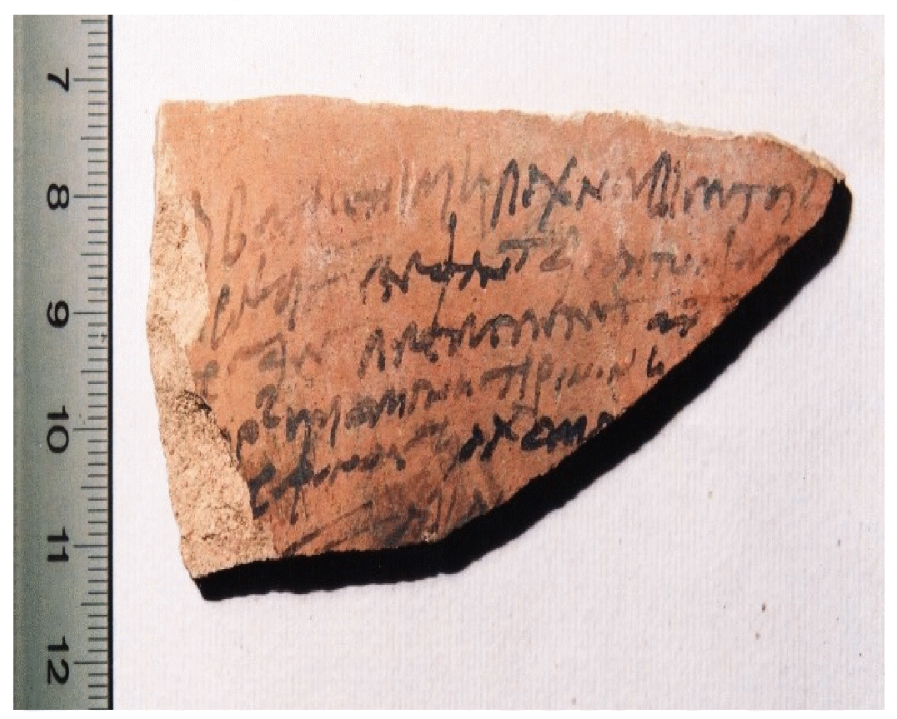

